$3-2003$

\title{
Estate Planning Malpractice: Is Strict Privity Here to Stay?
}

Angela M. Vallario

University of Baltimore School of Law, avallario@ubalt.edu

Follow this and additional works at: http://scholarworks.law.ubalt.edu/all_fac

Part of the Estates and Trusts Commons, Legal Ethics and Professional Responsibility Commons, and the Taxation-Federal Estate and Gift Commons

\section{Recommended Citation}

Estate Planning Malpractice: Is Strict Privity Here to Stay?, 36 Md. B.J. 18 (2003)

This Article is brought to you for free and open access by the Faculty Scholarship at ScholarWorks@University of Baltimore School of Law. It has been accepted for inclusion in All Faculty Scholarship by an authorized administrator of ScholarWorks@University of Baltimore School of Law. For more information, please contact snolan@ubalt.edu. 

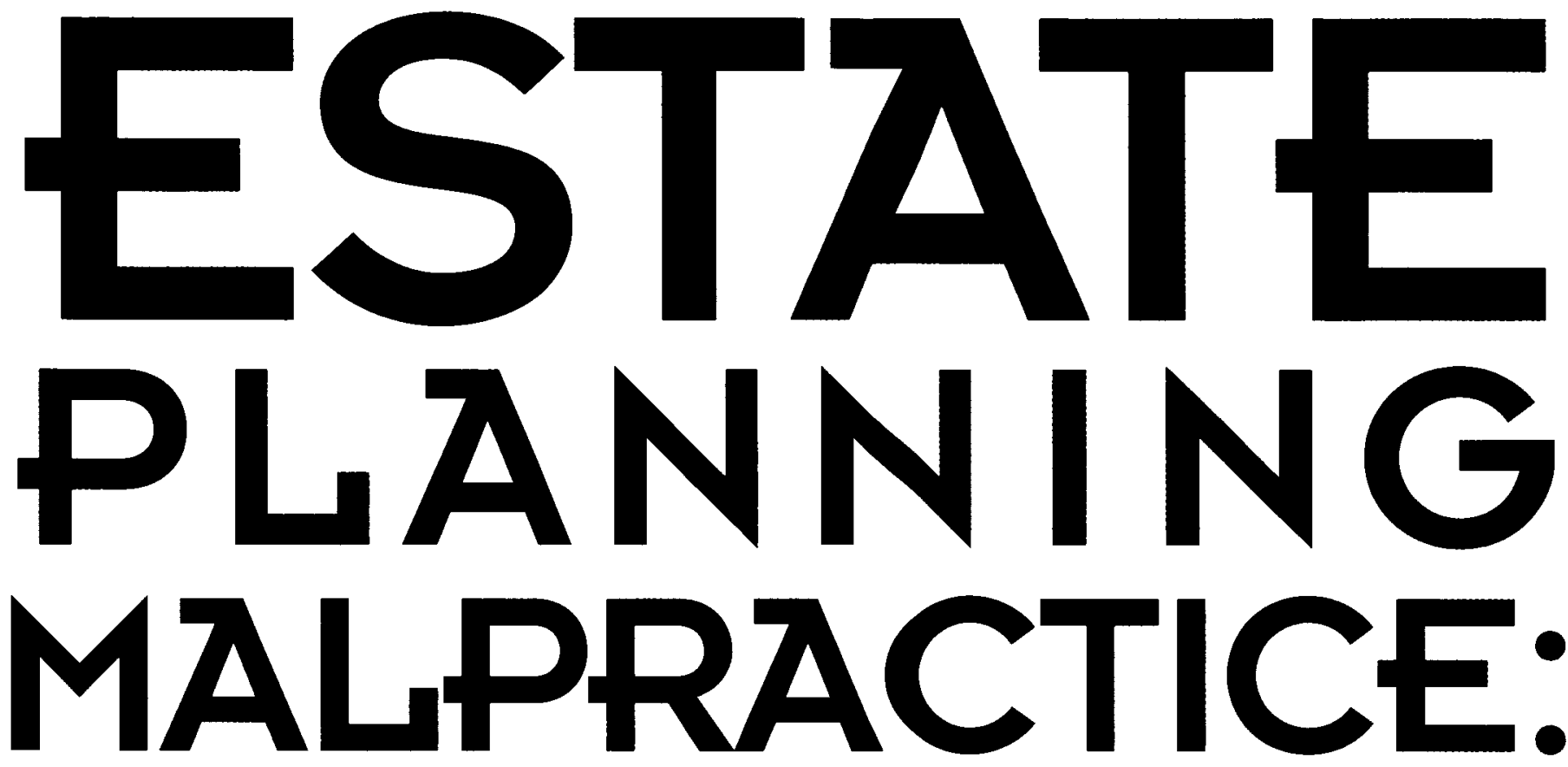

Is Strict Privity

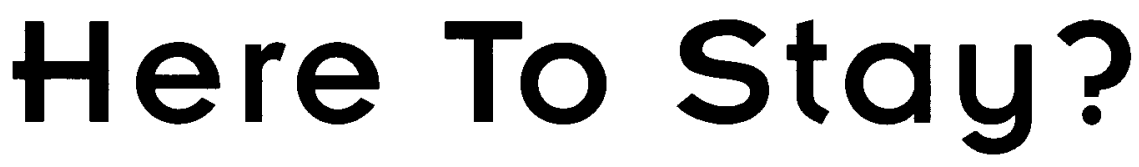

BY ANGELA MARIE VALLARIO 
nder Maryland case law, a plaintiff in an estate planning malpractice action must be in strict privity with the attorney who drafted the will. To date, Maryland has not extended the third-party beneficiary exception to the estate planning arena.

Legatees specifically identified in a will by name or class are generally precluded from bringing a cause of action against the attorney for the attorney's alleged negligence, because in Maryland in order to recover for legal malpractice, a plaintiff must show: "(1) the attorney's employment; (2) his neglect of a reasonable duty; and (3) loss to the client proximately caused by that neglect of duty." See Noble v. Bruce, $349 \mathrm{Md}$. 730, 739 (citing Flanherty v. Weinberg, 303 Md. 116, 128 (1985); see also Bradley Fogel, Attorney v. Client Privity, Malpractice, and the Lack of Respect for the Primacy of the Attorney-Client Relationship in Estate Planning, 68 Tenn. L. Rev. 261, 267 (2001).

Maryland is in the minority of states that still adhere to the strict privity rule in the context of estate planning. Most other jurisdictions have relaxed the privity barrier in order to allow a legitimately aggrieved beneficiary to have a means of recourse against an attorney who planned the distribution of the decedent's estate in a negligent manner. Other jurisdictions following strict privity, have carved out the third-party beneficiary exception in the estate-planning context where the attorney's negligence was "facially demonstrated" on the will itself. See Hamilton v. Needham, 519 A.2d 172 (D.C. 1988).

In Maryland, a plaintiff in a malpractice action must show that the attorney owed a duty of care to the plaintiff. Flaherty at 134 . The duty of care is generally shown by the presence of an attorney-client relationship between the plaintiff and the attorney. In the estate planning context, the attorney-client relationship is most often established between a decedent and the attorney who prepared the will. Because identified will beneficiaries are not generally part of the attorneyclient relationship, under Maryland case law they are likely precluded from suing the attorney for malpractice. The attorney who drafts the will owes a duty only to the decedent, who employed The attorney. Noble v. Bruce, 349 Md. 730, $752-53$ (1998).

Ms. Vallario is an Assistant Professor at the University of Baltimore School of Law.
The Court of Appeals has held that an attorney's duty is limited to his client because only "[a]client who has employed an attorney has a right to his diligence, his knowledge, and his skill; and [if] he...neglected to employ them, the law properly makes him liable for the loss which has accrued to his employer." Kendall $v$. Rogers, 181 Md. 606, 609 (1943) (citing Cochrane v. Little, $71 \mathrm{Md} .323$ (1889)). Allowing only the person who signed the will to sue the estate-planning attorney creates virtual immunity for those attorneys who make mistakes, because any negligence that has occurred, will most likely be discovered only after the death of the client who signed the will. The testamentary beneficiaries are the persons most likely damaged by the negligence, but they will be left without a remedy.

The personal representative of the decedent may have standing to sue; yet there are limited occasions upon which this cause of action will result in damages. Additionally if the negligence is discovered during the client's lifetime, the will can be amended without harm to the client and with no real liability for the attorney. Such mitigation of damage to the client is all to the good.

The cost to the attorney is the preparation of a codicil or new will without further compensation. There is the possibility that the client will still be alive but incompetent, which will preclude correcting the mistake by rewriting the will correctly. In that case a guardian or an attorney-in-fact could sue the attorney for malpractice but damages would be limited to the attorney fee paid. See Noble at 759.

The Court of Appeals has recognized the third-party beneficiary exception to the strict privity rule in contract cases. See Flaherty v. Weinberg, $303 \mathrm{Md} .116$ (1985). In Flaherty, third parties, not in contractual privity with the negligent attorney, stated a cause of action for negligent misrepresentation under a third-party beneficiary contract theory. The Flahertys contracted for the sale of a house and at the settlement, the attorney, Weinberg, assured them that the house they were buying was the property as described in the survey. When a subsequent survey revealed that the property purchased by the Flahertys encroached the neighboring property, the Flahertys brought suit against the attorney, upon theories of negligence and breach of warranty. Flaherty at 133.

In its reasoning, the court acknowledged that a prerequisite for maintaining an action in negligence against an attorney is the existence of an employment rela- 
tionship, but that an express agreement not necessary in all cases. The strict privity rule in the estate planning context was most recently addressed by the Court of Appeals in Noble, where the Court adhered to the strict privity rule thus barring the action by the will beneficiaries because there was no "employment relationship" between the attorney and the harmed beneficiaries.

The Noble Court refused to extend the third-party beneficiary exception to the testamentary beneficiaries because of the lack of communication between the attorney and the beneficiaries and the beneficiaries' lack of reliance on the attorney. The Court noted that the testamentary beneficiaries are not per se intended beneficiaries. Noble at 753. The Court of Appeals justified its decision on public policy grounds aimed at protecting the attorney-client relationship. The Court of Appeals found the strict privity rule protects: (1) the integrity and solemnity of the will; (2) the attorneyclient relationship and (3) attorney-client confidentiality. Id. at 756-758.

The Court of Appeals found the testamentary beneficiaries are not intended beneficiaries unless "the client's intent to benefit the nonclient [is] a direct purpose of the transaction or relationship." Id. at 753-54. The Court further noted that in cases involving wills, the beneficiary of a will is not necessarily the beneficiary of the attorney-client relationship. The Court speculated that the testator's intent and purpose in executing a will may not be to benefit the beneficiaries named in the will, but rather to prevent the intestate distribution of assets. Id. at 754 (emphasis added).

Moreover, the testator's intent could have been to exclude certain heirs or to dictate personally the dispositive scheme. Id. at 754. In reaching its decision, the Court considered essential ethical protections of the attorney-client relationship and feared that if it did not draw a clear line, there would be no limit on the number of people to whom an attorney would be obligated. Id. at

In Noble, the Court of Appeals of Maryland consolidated two separate malpractice actions brought by testamentary beneficiaries against the attorney who drafted the testator's will. In the first action, testamentary beneficiaries brought a cause of action of professional malpractice against attorneys who failed to incorporate a credit shelter trust, in the estate planning for Mr. and Mrs. Long. The attorney prepared mirror wills leaving all property to each other with a contingent provision for the distribution of the estate on the death of the survivor.

The contingent provisions called for certain real property to pass outright to one daughter; a partial interest in other real property passed to Mr. Long's sister; with the remainder passing subject to a life estate in a son, to their children as joint tenants with the right of survivorship. Shortly after the death of Mr. Long, Mrs. Long as the sole owner of all property received pursuant to the above-referenced mirror will transferred all real property to her sister and son. The remainder beneficiaries' complaint alleged that the attorney was negligent in rendering poor tax advice as estate taxes could have been eliminated with the use of a credit shelter trust which would have avoided the bunching of assets in their mother's estate. Id. at 734 .

In the second of the consolidated cases, the attorney prepared Ms. Jackson's will, which identified the Fauntleroys as the residual beneficiaries. The will also contained a tax provision. The tax provision caused $\$ 910,000$ of taxes to be paid from the residual estate. The Fauntleroys filed suit against the attorney's estate (because the attorney had died) alleging that he negligently prepared the will which caused all the taxes to be paid from the residuary estate. The beneficiaries' position was based on the allegation that this was contrary to the testatrix's intent. Id. at 737 .

In both instances, the alleged negligence is questionable and justifies the Court's adherence to the strict privity rule. With respect to the Longs, the testamentary beneficiaries allege that it was negligent for the attorney not to incorporate a credit shelter trust in the Longs' wills. The beneficiaries argued but for the negligence, the entire estate would have passed free of federal estate tax. Although most clients desire to minimize federal estate taxes in planning, there are a number of non-tax objectives that simply cannot be achieved with a credit shelter trust.

For example, in this case, Mrs. Long after the death of her husband would not have been able to transfer the real property if the parties had employed a credit shelter trust in Mr. Long's will. The very property Mrs. Long transferred would have been trust property held by the trustee which would have precluded Mrs. Long from singlehandedly transferring the property to her sister and son.

Furthermore, the attorney testified that credit shelter trusts were expressly rejected by the Longs because the survivor wanted control of the assets during his or her lifetime. Additionally, after Mr. Long's death, Mrs. Long could have disclaimed property she inherited from $\mathrm{Mr}$. Long to accomplish the tax savings that were forgone by the will that did not incorporate the credit shelter trust, but she did not. As to the Fauntleroys, the residual beneficiaries claimed that the attorney was negligent in avoiding the tax apportionment statute of Md. Tax Gen. $\$ 7-308$ by including a tax clause having all taxes paid from the residuary estate.

The case for negligence is weak because there are several reasons for the incorporation of a tax clause. With the facts in the Fauntleroy case, the Court was not willing to speculate as to the testamentary intent. In Noble, the Court rejected a change in Maryland law with respect to the strict privity rule in the estate-planning context. In reaching its decision, the Court agreed with the Court of Special Appeals' result, but not "all of its reasoning," in Kirgan v.Parks, 60 Md. 
App. 1, cert. denied, 301 Md. 639 (1984); Noble at 754.

In Kirgan, the court held that a testamentary beneficiary has no cause of action against the lawyer for alleged negligence in drafting the will when: (1) the will is valid; (2) the intent expressed in the will has been carried out; and (3) there was no concession of error by the attorney. Id. at 12-13. Thus because the Noble facts did not support a Kirgan cause of action, the Court applied the strict privity rule which prevented the testamentary beneficiaries from suing the attorney for legal malpractice. What remains unclear is whether the Court would carve out a third-party beneficiary exception where the beneficiary has demonstrated an obvious lack of care and skill on the part of the attorney. See Hamilton.

In a District of Columbia case, the testatrix's attorney failed to include a residuary clause in her will that resulted in a testamentary beneficiary being deprived of nearly $\$ 60,000$. While Hamilton's firm admitted the omission was negligent, the trial court denied recovery to Needham due to lack of privity. The Appellate Court reversed, holding that the testamentary beneficiary could maintain a malpractice action against the drafting attorneys despite lack of privity. Hamilton v. Needham, 459 A.2d 1060 (D.C. 1983).

Upon remand, Needham was awarded the money lost due to the negligent drafting. Hamilton appealed. Hamilton raised several issues on appeal. His first contention was that the trial court failed to require expert testimony on the attorney's standard of care. Hamilton, 519 A.2d at 173 . The court answered by noting that no complex issue was raised that required expert testimony and further stated that "a lawyer who admits that he omitted from a will a residuary clause requested by the testator and thereby causes the residual estate to pass by intestate succession has facially demonstrated an obvious lack of care and skill." Id. at 175.
Hamilton's next argument was that the testatrix had a duty to observe the omission, and her failure to do so should relieve him of liability. Id. The court dismissed his assertion by recognizing that the testatrix had a right to rely on Hamilton due to the fiduciary nature of their relationship. Id. Finally, Hamilton argued that the trial court erred in allowing extrinsic evidence to be admitted to show the testatrix's true intent. The court rejected this argument stating that without the admission of extrinsic evidence, the malpractice claim would be unprovable, thus leaving Needham without remedy. In a footnote, the court refused to adopt the rationale that extrinsic evidence may only be admitted to show that the testatrix's intent was frustrated. Id. at 175, n. 7 .

Specifically, the court noted that "Ithe testatrix's will was] silent as to the disposition of her residuary estate. Therefore, a finding that she intended that it pass to Needham is in no way contradictory to, nor does it frustrate, the language of the will itself. Indeed the absence of any residuary clause customary in a professionally drawn will coupled with a provision that any inheritance taxes due be a charge against 'my residuary estate' provide internal evidence within the will itself that something may be awry." Id.

Consider the following hypothetical:An elderly widow visits a Maryland attorney to prepare a will for a $\$ 150$ fee. The widow's blood relatives include an adult son and his daughter. The widow desires her twenty-five year old granddaughter to receive her house, bank account, and automobile. The widow's only son does not inherit under the will. The attorney drafts her will, which specifically devises her home to her granddaughter; bequeaths the cash in a SUNTRUST Bank and the automobile to the named granddaughter.

The will does not provide for a contingent beneficiary nor does the will include a residuary clause. Years pass and the widow decides to sell her home and relocates to an assisted living community. The $\$ 150,000$ cash from the sale of the home is invested in stock with Legg Mason. Her eyesight begins to fail and she is no longer able to drive so she sells her automobile and deposits the proceeds in her investment account with Legg Mason. Finally, she consolidates her assets by having her cash in SUNTRUST bank moved to a Legg Mason money market account. Several years go by and she dies.

Upon her death, the above referenced will devises and bequeaths assets that are no longer part of her probate estate. Although the will is valid in that it satisfies the statutory formalities of Md. Code Ann. Est. \& Trusts \$\$4-101; 4-102, it fails to dispose of property owned by the testatrix. Because the specifically devised and bequeathed properties are no longer in existence, the properties adeem and the granddaughter receives nothing. Since the testatrix's Legg Mason account was not disposed of by her valid will, the rules of intestate succession control its disposition. The son as her sole heir receives the widow's entire estate pursuant to Md. Code Ann. Est. \&Trusts §3-103.

The attorney documents that there was a discussion of a residuary clause between him and his client, which was rejected. Her preference was to itemize her assets and dispose of them as done by the will prepared. The question that arises is whether the granddaughter can bring a malpractice action against the attorney for failing to include a residuary provision, which provided for her. If the failure to include a residuary clause in any will constitutes malpractice (See 7 Am. Jur.2d Attorneys at Law \$\$212-253; J.A. Bock, Annotation, Liability of One Drawing an Invalid Will, 65 A.L.R.2d 1363 (1959)) then does the granddaughter have standing to sue? If the testamentary beneficiary has standing to sue would her recovery be limited to the $\$ 150$ fee? 
One could argue that under Kirgan "the intent expressed in the will" has not been carried out and thus the granddaughter has a malpractice action against the attorney for malpractice. Kirgan at 12-13 (text item 2). Yet the Maryland Courts have stated that "where the language of a will is plain and unambiguous, extrinsic evidence is not admissible to show that the testator's intention was different from that which the will discloses, because evidence intended to alter the language of the will would violate the statute." Noble at 749.

Moreover, "extrinsic evidence is not admissible to show that the testator's intent was different from that expressed in the will. Attorney malpractice cases involving nonclients and arising out of will drafting or estate planning require special considerations because the testator is dead. If extrinsic evidence were admitted, the potential for fraud and the risk of misinterpreting the testator's intent increases dramatically." Noble at 754 (citing Espinosa v. Sparber, Shevin, Shapo, Rosen and Heilbronner, 612 So.2d 1378 (Fla. 1993)).

In light of the rules of evidence necessary to protect the solemnity of a will the hypothetical facts do not support a Kirgan cause of action by the granddaughter. Kirgan allows a testamentary beneficiary to sue the attorney in legal malpractice if there is a concession of error by the attorney. Kirgan at 12-13 (text item 3).

Because the hypothetical attorney does not admit any negligence, the testamentary beneficiary cannot sue the attorney. In the estate-planning setting where there is an unambiguous valid will, as long as the attorney's conduct does not escalate to the level of fraud or collusion, if there is no acknowledgment of negligence on the part of the attorney, the testamentary beneficiary does not have standing to sue in Maryland. See Noble at 738 (citing National Savings
Bank v. Ward, 100 U.S. 195, 205-206 (1879)).

A distinction can be made between the hypothetical facts and the Noble case, however, which warrants deviation from the strict privity rule. In Noble there were plausible explanations for the estate planning performed by the attorneys. In light of the possible reasons for the documents to be in their current form, the court was unwilling to speculate as to the testamentary intent without the ability to confer with the decedents. If the facts of the hypothetical case provide no reasonable justification for the attorney's failure to include a residuary provision in a will, then the failure to include a residuary provision in a will constitutes negligence for which a legal malpractice action should be brought.

Because the possible negligence was discovered upon the death of the testatrix, the law should provide protection for the testamentary beneficiary who was harmed by the negligence and will otherwise be left without a remedy. In Hamilton, the court stated "a lawyer who admits that he omitted from a will a residuary clause required by the testator and thereby causes the residual estate to pass by intestate succession has facially demonstrated an obvious lack of care and skill." Hamilton at 175.

Moreover, the absence of any residuary clause customary in a professionally drawn will coupled with a tax provision provide "internal evidence within the will itself that something may be awry" Id. at _.

The hypothetical facts are distinguishable also from Hamilton in two ways. First there was no admission by the attorney and secondly there was no tax provision. These distinctions might not result in a different outcome.

\section{Conciuston}

Extending the third-party beneficiary exception to a situation where there is an obvious lack of care and skill with no plausible explanation for the alleged negligence would not open the floodgates of litigation. There would be a clear limitation concerning the persons to whom the attorney would be obligated, and under what circumstances the obligation would arise. If the courts overcome strict privity in situation where the document facially demonstrates an obvious lack of care and skill, the issue of damages arises. Dicta in Noble suggests that if a cause of action were allowed by the testamentary beneficiaries that the damages would be limited to the attorney fee. Noble at 759.

In effect that would mean no real recovery at all. If the Court extends the third-party beneficiary exception to testamentary beneficiaries where there is an obvious lack of care and skill, the Court should entitle the harmed beneficiaries to their actual damages. Current Maryland law suggests that no matter how heinous conduct of a estate-planning attorney, the strict privity rule shields the attorney. The testamentary beneficiaries may be able to file a grievance complaint against the attorney. Such a complaint will not compensate the beneficiaries, so there is no real remedy for the harm caused.

Perhaps the attorney's conduct in Noble did not rise to the level of egregiousness necessary to overcome the strict privity rule in Maryland. At some point, it is hoped the courts will draw the line to lift the strict privity rule barrier to relief for a testamentary beneficiary who falls victim to the gross negligence of the drafting attorney. Although the Court of Appeals has not yet carved out the thirdparty beneficiary exception needed to allow testamentary beneficiaries to sue the attorney, it is unlikely that the Court will continue to allow the strict privity barrier to shelter gross negligence, particularly when the estate planning document facially demonstrates an obvious lack of care and skill. 


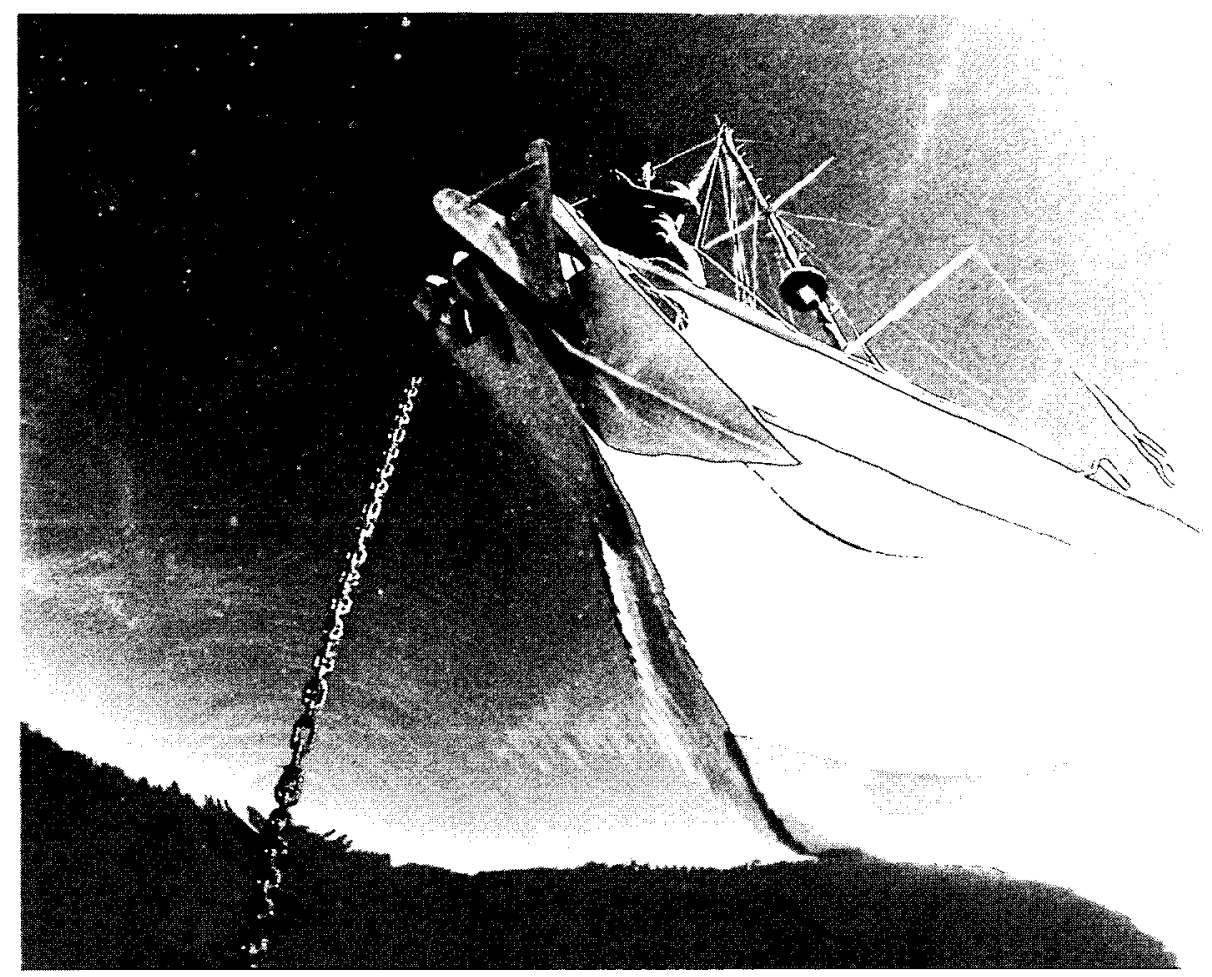

WHAT CAN AN

\section{A N G H O R}

TEACH US ABOUT

\section{W E A L T H M A N A G E M E N T ?}

It should be close at hand and have a lot of weight behind it

We learn from the world around us. And from the community in which we live and work. With a team of seasoned financial specialists rooted in Maryland, Wachovia Wealth Management brings an unparalleled focus to successful individuals and their families. As the area's largest, most firmly established provider of trust services, we are best prepared to help you grow, preserve and transfer wealth. Talk to us. Call J. Jeffrey Haines, Esq., CPA, Estate and Financial Planning Advisor, 410.332.5261.

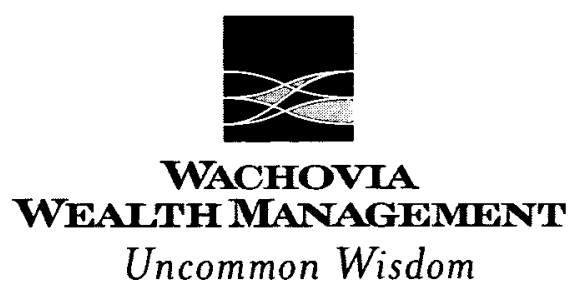




\section{Trustee

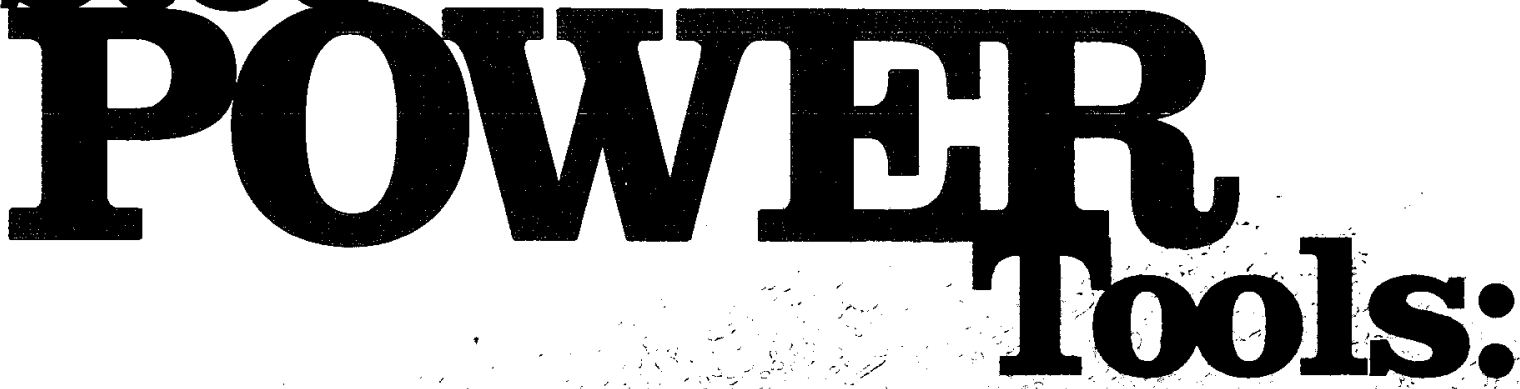

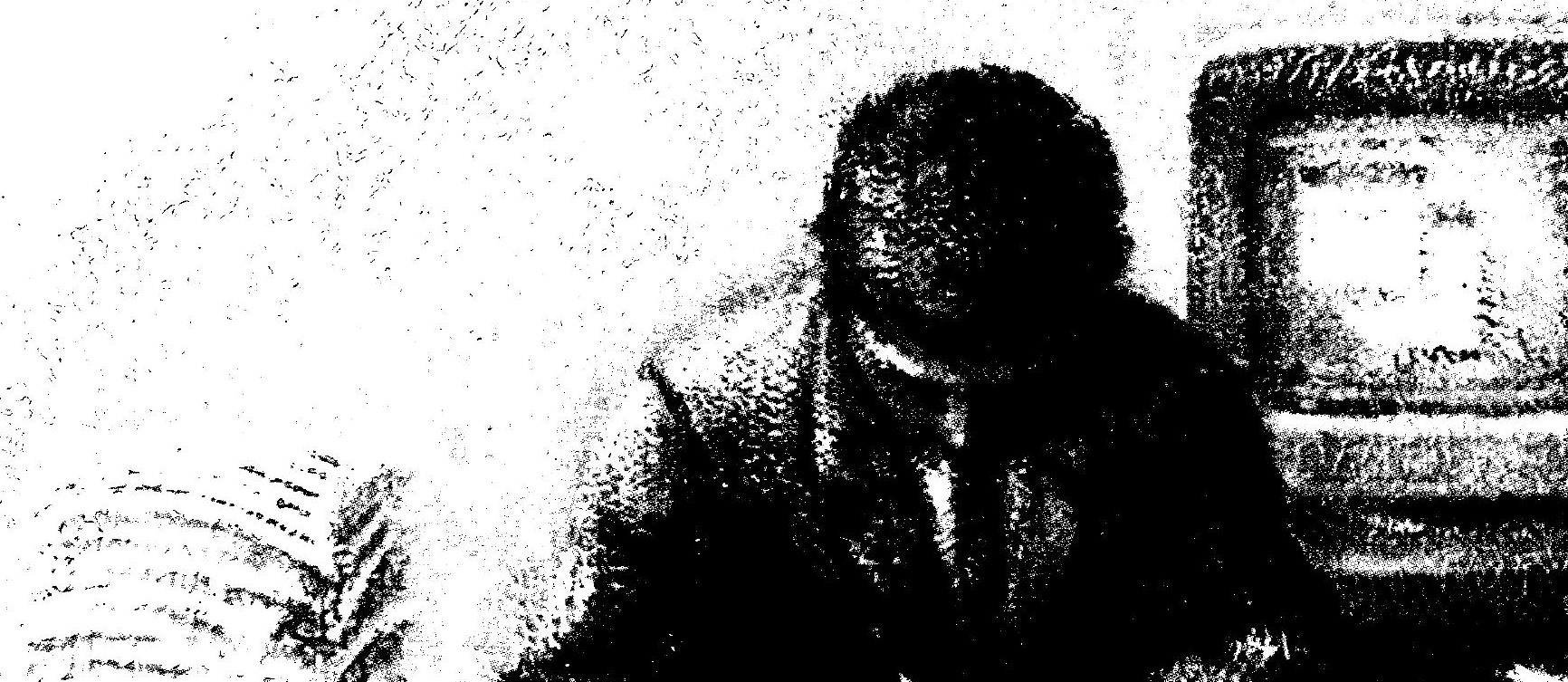
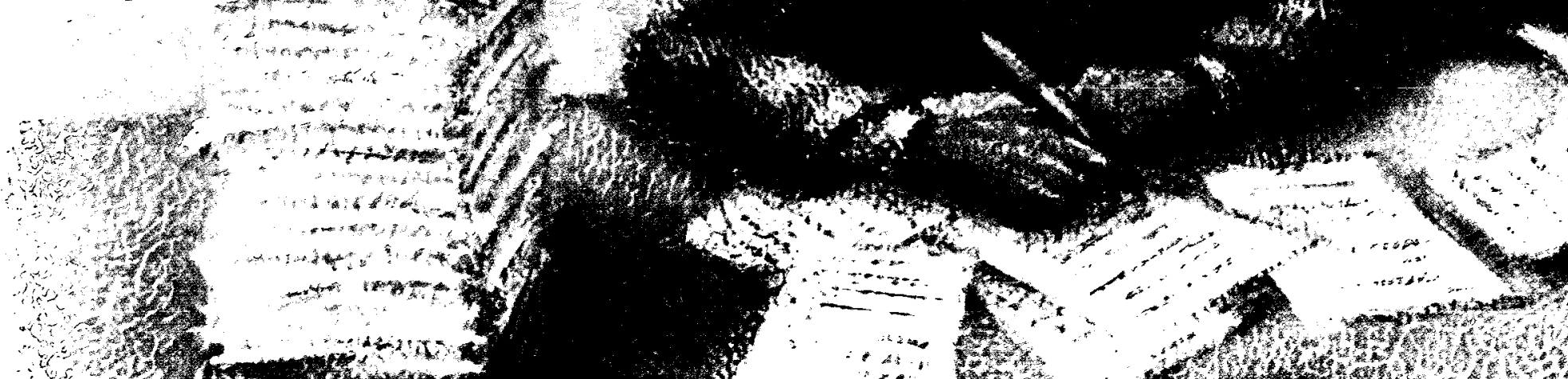